\title{
Improvement of Functional Properties of Whey Protein Isolate Through Glycation and Phosphorylation by Dry Heating
}

\author{
C. P. Li, ${ }^{1}$ H. Enomoto, ${ }^{1}$ S. Ohki ${ }^{2}$ H. Ohtomo, ${ }^{2}$ and T. Aoki ${ }^{1}$ \\ ${ }^{1}$ Department of Biochemical Science and Technology, Faculty of Agriculture, Kagoshima University, \\ Kagoshima 890-0065, Japan \\ ${ }^{2}$ Food Technology Research Institute, Division of Research and Development, Meiji Dairies Corporation, \\ 540 Naruda, Odawara, Kanagawa 250-0862, Japan
}

\begin{abstract}
Whey protein isolate (WPI) was glycated with maltopentaose (MP) through the Maillard reaction, and the MP-conjugated WPI (MP-WPI) was then phosphorylated by dry heating in the presence of pyrophosphate. Glycation occurred efficiently, and the sugar content of WPI increased approximately $19.9 \%$ through the Maillard reaction. The phosphorylation of MP-WPI was enhanced with an increase in the dry-heating time from 1 to $5 \mathrm{~d}$, and the phosphorus content of WPI increased approximately $1.05 \%$ by dry heating at $\mathrm{pH} 4.0$ and $85^{\circ} \mathrm{C}$ for $5 \mathrm{~d}$ in the presence of pyrophosphate. The electrophoretic mobility of WPI increased with an increase in the phosphorylation level. The stability of WPI against heat-induced insolubility at $\mathrm{pH} 7.0$ was improved by conjugation with MP alone, and further improved by phosphorylation. Although the emulsifying activity of WPI was barely affected by glycation and phosphorylation, the emulsifying stability of phosphorylated MPWPI ( $5 \mathrm{~d}$ ), was 2.2 times higher than that of MP-WPI. Gelling properties such as hardness, resiliency, and water-holding capacity of heat-induced WPI gel were markedly improved, and the gel was rendered transparent by phosphorylation. The calcium phosphate-solubilizing ability of WPI was enhanced by phosphorylation. These results suggested that phosphorylation by dry heating in the presence of pyrophosphate after conjugation with MP is a useful method for improving the functional properties of WPI.
\end{abstract}

(Key words: phosphorylation, whey protein isolate, Maillard reaction, functional property)

Abbreviation key: C-WPI = control WPI, DH-WPI = WPI dry-heated in the absence of maltopentaose and pyrophosphate, EWP = egg white protein, $\mathbf{M P}=$ maltopentaose, MP-WPI = WPI conjugated with maltopentaose by Maillard reaction, $\mathbf{P i}=$ inorganic phosphorus,

Received July 20, 2005.

Accepted August 19, 2005.

Corresponding author: T. Aoki; e-mail: aoki@chem.agri. kagoshima-u.ac.jp.
PP-MP-WPI = phosphorylated MP-WPI by dry heating in the presence of pyrophosphate, WHC = water-holding capacity, WPI = whey protein isolate.

\section{INTRODUCTION}

Dried whey powders, a major by-product of cheese and casein manufacturing, have become well known for use in the food industry due to their low price, versatility with respect to functionality, and high nutritive value as an ingredient in food products (Kim et al., 1981). Advances in processing technology such as ultrafiltration, microfiltration, reverse osmosis, and ion exchange have resulted in the development of several different final whey products. Whey protein isolate (WPI), one such whey product usually isolated using ion-exchange technology, is used in food products to increase viscosity, form gels, stabilize emulsions or foams, or as a water-holding agent (Kinsella and Whitehead, 1989). The effective use of protein in food processing systems is dependent on tailoring the protein's functional characteristics to meet the complex needs of manufactured food products (Chobert, 2003). There is a need to improve the functional properties of WPI to maximize the efficiency of its use in the food industry.

Phosphorylation has been proven to be a useful method for improving the functional properties of food proteins (Woo and Richardson, 1983; Matheis and Whitaker, 1984; Seguro and Motoki, 1989; Aoki et al., 1994, 1997; Kato et al., 1995; Sitohy et al., 1995). Recently, we succeeded in phosphorylating egg white protein (EWP) by dry heating in the presence of phosphate (Li et al., 2003, 2004), significantly improving the heat stability, emulsifying properties, and gelling properties of EWP (Li et al., 2004). Furthermore, the calcium phosphate-solubilizing ability of EWP was enhanced by phosphorylation. However, WPI showed a lower phosphorylation level than that of EWP by dry heating under the same conditions, and this was due to a lower sugar content of WPI (Li et al., 2003). The saccharides or sugar chains in protein are phosphorylated by dry 
heating in the presence of phosphate (Tarelli and Wheeler, 1994; Sitohy et al., 2000; Nakano et al., 2003), suggesting that introduction of sufficient sugar may result in more efficient phosphorylation of WPI by dry heating in the presence of phosphate.

In the present study, to obtain an effectively phosphorylated WPI with improved functional properties, WPI was glycated with maltopentaose (MP) through the Maillard reaction, and the MP-WPI conjugate was then phosphorylated by dry heating in the presence of pyrophosphate. Lastly, we investigated the functional properties of phosphorylated MP-WPI (PP-MP-WPI).

\section{MATERIALS AND METHODS}

\section{Materials}

Whey protein isolate was purchased from Taiyo Kagaku Co., Ltd. (Yokkaichi, Japan) and MP from Nacalai Tesque Co., Ltd. (Kyoto, Japan). All other reagents were of analytical grade.

\section{Preparation of WPI}

Control WPI (C-WPI) and MP (1:0.3 wt/wt) were dissolved in Milli-Q water at a protein concentration of 20 $\mathrm{g} / \mathrm{L}$, and the solution $\mathrm{pH}$ was adjusted to 8.0 with $1 M$ $\mathrm{NaOH}$, followed by lyophilization. The dried sample was kept at $50^{\circ} \mathrm{C}$ and $65 \% \mathrm{RH}$ for $3 \mathrm{~d}$ using a saturated $\mathrm{KI}$ solution in a desiccator according to a previous paper (Aoki et al., 2001), and was then dissolved in $0.1 \mathrm{M}$ sodium pyrophosphate buffer at $\mathrm{pH}$ 4.0. The lyophilized samples were incubated at $85^{\circ} \mathrm{C}$ for 1,3 , and $5 \mathrm{~d}$ according to the previous paper (Li et al., 2004), and the dry-heated samples were then dissolved in Milli-Q water. The solution was dialyzed to remove free pyrophosphate and MP for $3 \mathrm{~d}$ against Milli-Q water (molecular weight cut-off $=10,000$ ) and then lyophilized.

For the preparation of WPI conjugated with MP (MPWPI), C-WPI and MP (1:0.3 wt/wt) were dissolved in Milli-Q water at a protein concentration of $20 \mathrm{~g} / \mathrm{L}$, and the $\mathrm{pH}$ value of the solution was adjusted to 8.0 with $1 M \mathrm{NaOH}$, followed by lyophilization. The dried sample was kept at $50^{\circ} \mathrm{C}(65 \% \mathrm{RH})$ for $3 \mathrm{~d}$ using a saturated $\mathrm{KI}$ solution in a desiccator, then dialyzed against Milli$\mathrm{Q}$ water for $3 \mathrm{~d}$, after which the solution was then lyophilized. For preparation of dry-heated WPI (DHWPI), C-WPI was dissolved in Milli-Q water at a concentration of $20 \mathrm{~g} / \mathrm{L}$ and the $\mathrm{pH}$ was adjusted to 4.0 , and the solution was then lyophilized. The dried sample was dry-heated at $85^{\circ} \mathrm{C}$ for $5 \mathrm{~d}$. Finally, the sample was dialyzed against Milli-Q water for $3 \mathrm{~d}$ and then lyophilized.

\section{Determination of Sugar Content}

The total sugar contents of C-, DH-, MP-, and PP-MPWPI were determined using the phenol-sulfuric acid method (Dubois et al., 1956). For the determination of free sugar, $2 \mathrm{~mL}$ of a $10 \mathrm{~g} / \mathrm{L}$ WPI solution was ultrafiltered through Centrisalt I (Sartorius AG-W-3400 Goetingen, Germany; molecular mass cut off $=10,000$ ). The sugar content in the ultrafiltrate was regarded as free sugar. The sugar bound to WPI was estimated by the difference between the total and free sugar content.

\section{Determination of Phosphorus Content}

Protein samples were digested in perchloric acid. Phosphorus in the digest was regarded as the total phosphorus of protein. For the determination of inorganic phosphorus $(\mathbf{P i}), 2 \mathrm{~mL}$ of $10 \mathrm{~g} / \mathrm{L}$ WPI solution was ultrafiltered through Centrisalt I (Sartorius AG-W3400; molecular mass cut off $=10,000$ ). The phosphorus content in the ultrafiltrate was regarded as Pi. The $\mathrm{P}$ content was determined by the method of Chen et al. (1956). The amount of phosphorus bound to proteins was estimated by the difference between the total phosphorus and Pi content.

\section{Measurement of Solubility}

Whey protein isolate samples were dissolved at a concentration of $1 \mathrm{~g} / \mathrm{L}$ in $50 \mathrm{mM}$ Tris-HCl buffer $(\mathrm{pH}$ 7.0), and then centrifuged at $3000 \times g$ for $15 \mathrm{~min}$. The concentration of protein in the supernatant was determined by the absorbance value at $280 \mathrm{~nm}$.

\section{Electrophoresis}

Native PAGE was performed using $14 \%$ gels in the absence of SDS, and SDS-PAGE using $14 \%$ polyacrylamide gels under both reducing and nonreducing conditions in the presence and absence of 2-mercaptoethanol according to the method of Laemmli (1970). The gels were stained in Coomassie Blue R-250 for $1 \mathrm{~h}$.

\section{Measurements of Stability of WPI Against Heat-Induced Insolubility}

Protein samples were dissolved at a concentration of $0.1 \%$ in $50 \mathrm{~m} M$ Tris-HCl buffer ( $\mathrm{pH} 7.0$ ). The sample solutions $(1 \mathrm{~mL})$ were placed in small test tubes with aluminum foil stoppers and were heated in a water bath at 60 to $100^{\circ} \mathrm{C}$ for $10 \mathrm{~min}$. Aggregates were precipitated by centrifugation at $15,000 \times g$ for $30 \mathrm{~min}$. The soluble protein in the supernatant was measured to estimate the protein concentration of the solution by the absorbance value at $280 \mathrm{~nm}$. 


\section{Measurement of Emulsifying Properties}

The emulsifying properties of C-, DH-, MP-, and PPMP-WPI were measured by the method of Pearce and Kinsella (1978). The protein concentrations in WPI samples determined by Kjeldahl method were adjusted to $0.1 \%$, and the sugar contents of WPI samples were adjusted to $19.9 \%$ by adding maltopentaose into WPI solutions. To $3 \mathrm{~mL}$ of a $0.1 \%$ protein sample in $0.1 \mathrm{M}$ phosphate buffer ( $\mathrm{pH} 7.4$ ), $1 \mathrm{~mL}$ of corn oil was added, after which the mixture was homogenized at 12,000 rpm at $20^{\circ} \mathrm{C}$ for $1 \mathrm{~min}$ with a PT10-35 Polytron homogenizer (Kinematic Ag, Lucerne, Switzerland). From the bottom of each test tube, $100 \mu \mathrm{L}$ of emulsion was taken out at different times and diluted with $4 \mathrm{~mL}$ of $0.1 \%$ SDS solution. The absorbance of the diluted emulsion was then determined at $500 \mathrm{~nm}$. The emulsifying activity was determined from the absorbance measured immediately after emulsification. The emulsion stability was estimated by determining the half time of the turbidity measured immediately after emulsion formation.

\section{Effect of $\mathrm{NaCl}$ Concentration on Appearance of WPI Gel}

The sample was dissolved in $0 \sim 200$ with an interval of $25 \mathrm{mM} \mathrm{NaCl}$ solution to give a protein concentration of $100 \mathrm{~g} / \mathrm{L}$ as determined by Kjeldahl method, and adjusted to $\mathrm{pH} 7.0$ with $1 \mathrm{M} \mathrm{NaOH}$. The sugar contents of WPI samples were adjusted to $19.9 \%$ by adding maltopentaose into WPI solutions. Two hundred microliters of WPI solutions were transferred to each well of a 96well microplate after being degassed under vacuum for $1 \mathrm{~h}$, and the plate was covered with a plastic film. The microplate was then heated in an incubator at $90^{\circ} \mathrm{C}$ for $1 \mathrm{~h}$. The absorbance at $595 \mathrm{~nm}$ of solution was measured using a BioRad 550 microplate reader (BioRad Laboratories, Inc., Hercules, CA) after being heated according to the method of Kitabatake and Kinekawa (1995).

\section{Preparation of Heat-Induced Gels for Measurement of Gelling Properties}

The sample was dissolved in Milli-Q water containing $75 \mathrm{~m} M \mathrm{NaCl}$ to prepare a $100 \mathrm{~g} / \mathrm{L}$ WPI solution, which was transferred into a cylindrical casing tube made of polyvinylidene chloride (diameter $=13 \mathrm{~mm}$, height $=$ $100 \mathrm{~mm}$ ), and then heated in a water bath at $90^{\circ} \mathrm{C}$ for $30 \mathrm{~min}$. The gels were immediately cooled to room temperature by immersion in tap water for $30 \mathrm{~min}$, and allowed to stand at room temperature for $1 \mathrm{~h}$. They were sectioned at $15 \mathrm{~mm}$ thickness and used for the measurement of mechanical properties at ambient temperature, which was carried out using a Yamaden RE3305 rheometer (Yamaden Co., Ltd., Tokyo, Japan) equipped with a cylindrical plunger with a cross-sectional area of $0.283 \mathrm{~cm}^{2}$ (diameter $=6 \mathrm{~mm}$ ). The plunger descended at a rate of $0.2 \mathrm{~mm} / \mathrm{s}$ until the gel ruptured, and its direction was then reversed to move upward at the same speed. The hardness and resiliency of the gels were calculated from the force-deformation curves as follows (Kang et al., 1991):

Hardness $=$ maximum force $\left(\right.$ gram-force $\left./ \mathrm{cm}^{2}\right)$ at rupture in the compression curve.

Resiliency $=$ (area under the decompression curve/area under the compression curve) $\times 100 \%$.

For measuring the water-holding capacity (WHC) of WPI gel, a $100 \mathrm{~g} / \mathrm{L}$ WPI solution prepared as described above was put into a cylindrical vinyl chloride plastic casing (diameter $=13 \mathrm{~mm}$, height $=150 \mathrm{~mm}$ ), and then heated in a water bath at $90^{\circ} \mathrm{C}$ for $30 \mathrm{~min}$. The gels were immediately cooled to room temperature by immersion in tap water for $30 \mathrm{~min}$, and allowed to stand at room temperature for $1 \mathrm{~h}$. They were then sectioned at $10 \mathrm{~mm}$ thickness and used for measurement of WHC. Water-holding capacity of gel was calculated from the formula

$$
W_{1} \times 100 / W_{0} \times 100 \%,
$$

where $W_{0}$ was the initial gel weight and $W_{1}$ was the gel weight after being laid on 5 layers of filter paper (No. 2, diameter $=110 \mathrm{~mm}$, Advantec Toyo Kaisha Ltd., Tokyo, Japan) at ambient temperature $\left(25 \pm 1^{\circ} \mathrm{C}\right)$ for $1 \mathrm{~h}$.

\section{Measurement of Solubilization of Calcium Phosphate}

The preparation of test solutions was conducted according to the procedures for artificial casein micelles (Aoki, 1989). Forty microliters of $1.0 \mathrm{M}$ potassium citrate, $200 \mu \mathrm{L}$ of $0.2 \mathrm{M} \mathrm{CaCl}_{2}$, and $240 \mu \mathrm{L}$ of $0.2 \mathrm{M}$ $\mathrm{K}_{2} \mathrm{HPO}_{4}$ were added to $2 \mathrm{~mL}$ of $4 \%$ protein solution, followed by the addition of $200 \mu \mathrm{L}$ of $0.2 \mathrm{M} \mathrm{CaCl}_{2}$, and $100 \mu \mathrm{L}$ of $0.2 \mathrm{M} \mathrm{K}_{2} \mathrm{HPO}_{4}$. The addition of $200 \mu \mathrm{L}$ of 0.2 $M \mathrm{CaCl}_{2}$ and $100 \mu \mathrm{L}$ of $0.2 M \mathrm{~K}_{2} \mathrm{HPO}_{4}$ was repeated to yield calcium and Pi concentrations of 30 and $22 \mathrm{mM}$, respectively. The interval set for addition was $15 \mathrm{~min}$, and all additions were accompanied by stirring at $\mathrm{pH}$ 6.7. The volume was adjusted to $4 \mathrm{~mL}$ by measuring the weight of solution. The prepared solutions were allowed to stand for $20 \mathrm{~h}$ at $25^{\circ} \mathrm{C}$, and then centrifuged at $3000 \times \mathrm{g}$ for $15 \mathrm{~min}$. The calcium and $\mathrm{Pi}$ in the supernatant were then determined, with the former being determined using a Hitachi Z-600 atomic absorp- 
Table 1. Some characteristics of the whey protein isolates (WPI) evaluated. ${ }^{1}$

\begin{tabular}{lclc}
\hline Sample $^{2}$ & $\begin{array}{l}\text { Sugar } \\
(\%)\end{array}$ & $\begin{array}{l}\text { P } \\
(\%)\end{array}$ & $\begin{array}{l}\text { Solubility } \\
(\%)\end{array}$ \\
\hline C-WPI & 1.5 & 0.04 & 100.0 \\
DH-WPI & 1.5 & 0.04 & 99.3 \\
MP-WPI & 12.1 & 0.02 & 99.1 \\
PP-MP-WPI-1d & 19.7 & 0.60 & 99.8 \\
PP-MP-WPI-5d & 19.9 & 1.05 & 99.4 \\
\hline
\end{tabular}

${ }^{1}$ All data shown are the mean value of the 2 determinations, with a deviation of $<1 \%$.

${ }^{2} \mathrm{C}-\mathrm{WPI}=$ control WPI; DH-WPI $=$ WPI dry heated at $\mathrm{pH} 4.0$ and $85^{\circ} \mathrm{C}$ for $5 \mathrm{~d}$ in the absence of pyrophosphate; MP-WPI = WPI conjugated with maltopentaose by incubation at $50^{\circ} \mathrm{C}(65 \% \mathrm{RH})$ for $3 \mathrm{~d}$; PP-MP-WPI $=$ MP-WPI dry heated at $\mathrm{pH} 4.0$ and $85^{\circ} \mathrm{C}$ for 1 and 5 $d$ in the presence of pyrophosphate.

tion spectrophotometer (Hitachi Ltd., Tokyo, Japan; Aoki, 1989).

\section{RESULTS AND DISCUSSION}

\section{Characteristics of Phosphorylated WPI}

Whey protein isolate was conjugated with $\mathrm{MP}$ at $\mathrm{pH}$ 8.0 and $50^{\circ} \mathrm{C}$ for $3 \mathrm{~d}$, and MP-WPI was then phosphorylated by dry heating in the presence of pyrophosphate. In the present study, $3 \mathrm{~d}$ of reaction time was used because the sugar content of glycated protein increased gradually until $3 \mathrm{~d}$ of incubation with MP (Aoki et al., 2001). Table 1 shows some characteristics of the different WPI studied. As shown in Table 1, C- and DHWPI contained only a small amount of sugar $(\sim 1.5 \%)$. However, after incubation with $\mathrm{MP}$ at $50^{\circ} \mathrm{C}(\mathrm{RH} 65 \%)$ for $3 \mathrm{~d}$, the sugar content of WPI increased to $12.1 \%$, and further increased to 19.7 and $19.9 \%$ by dry heating at $\mathrm{pH} 4.0$ and $85^{\circ} \mathrm{C}$ for 1 and $5 \mathrm{~d}$, respectively, in the presence of MP and pyrophosphate. This suggested that further glycation occurred by Maillard reaction at $\mathrm{pH}$ 4.0 and $85^{\circ} \mathrm{C}$. This result also suggested that glycation occurred efficiently on proteins in WPI. The phosphorus contents of C-, DH-, and MP-WPI were less than $0.05 \%$, whereas that of MP-WPI increased to $0.60 \%$ by dry heating at $\mathrm{pH} 4.0$ and $85^{\circ} \mathrm{C}$ for $1 \mathrm{~d}$ in the presence of pyrophosphate (PP-MP-WPI-1d), and further to $1.05 \%$ by dry-heating for $5 \mathrm{~d}$ (PP-MP-WPI-5d), which was higher than that of bovine whole casein (Fox, 2003). In a previous study (Li et al., 2004), we phosphorylated EWP by dry heating in the presence of pyrophosphate to yield a phosphorus content of phosphorylated EWP of $1.05 \%$, which was considered to be a phosphorus content sufficient for improving the functional properties of EWP. In the present study, the phosphorus content of glycated WPI was very close to that of EWP under the same reaction conditions. These results indi- cated that efficient phosphorylation occurred in WPI by dry heating in the presence of pyrophosphate after conjugation with MP. The solubility of food protein is an important property for its application in food processing. Almost no effect of the Maillard reaction or phosphorylation on the solubility of WPI at $\mathrm{pH} 7.0$ was observed, and even when dry heated for $5 \mathrm{~d}$ in the presence of pyrophosphate, the solubility of WPI was $99.4 \%$.

Native PAGE and SDS-PAGE were performed to elucidate, respectively, the changes of charge in protein and the bonds formed in protein aggregates by phosphorylation after glycation. As shown in Figure 1A (native PAGE), although there were almost no changes in the mobility of C- and DH-WPI components, the mobility of protein bands other than the band at the top of gel sheet in MP-WPI decreased. This might be caused by the introduction of MP to the WPI components and the subsequent increase of their molecular mass. On the other hand, compared with MP-WPI, the mobility of protein increased with an increase in dry-heating time from 1 to $5 \mathrm{~d}$ in the presence of pyrophosphate, and that increase of mobility was in agreement with the phosphorylation level (Table 1). These results indicated that a higher level of negatively charged phosphate groups on WPI caused greater mobility. To assess the binding type of aggregates, we performed SDS-PAGE in the absence and presence of 2-mercaptoethanol. As shown in Figure 1B, a band at the top of the gel sheet in C-WPI was observed in the absence of 2-mercaptoethanol, whereas it disappeared in the presence of 2-mercaptoethanol, suggesting that a slight aggregation caused by disulfide bonds may have occurred during the heat treatment of WPI. That aggregate increased by dry heating at $\mathrm{pH} 4.0$ and $85^{\circ} \mathrm{C}$ for $5 \mathrm{~d}$ in the absence of MP and pyrophosphate, but there were almost no changes in the mobility of the major protein components. However, the mobility of 2 major proteins $(\beta$ LG and $\alpha$-LA) in WPI decreased by glycation, and a different molecular mass of these proteins was observed in the absence of 2-mercaptoethanol. This observation indicated that the molecular mass of $\beta$-LG and $\alpha$-LA increased by conjugation with MP, which might explain why the mobility of WPI components decreased by conjugation with MP in the native PAGE (Figure 1A). In the absence of 2-mercaptoethanol, the intensities of the bands of MP-conjugated proteins decreased with an increase in dry-heating time from 1 to $5 \mathrm{~d}$. On the other hand, in the presence of 2-mercaptoethanol, the intensities of the bands of proteins in MP- and PP-MP-WPI increased, suggesting that the formation of some of the polymerization between whey protein components was caused by a sulfhydryl-disulfide interchange reaction through dry heating in the absence or presence of pyro- 


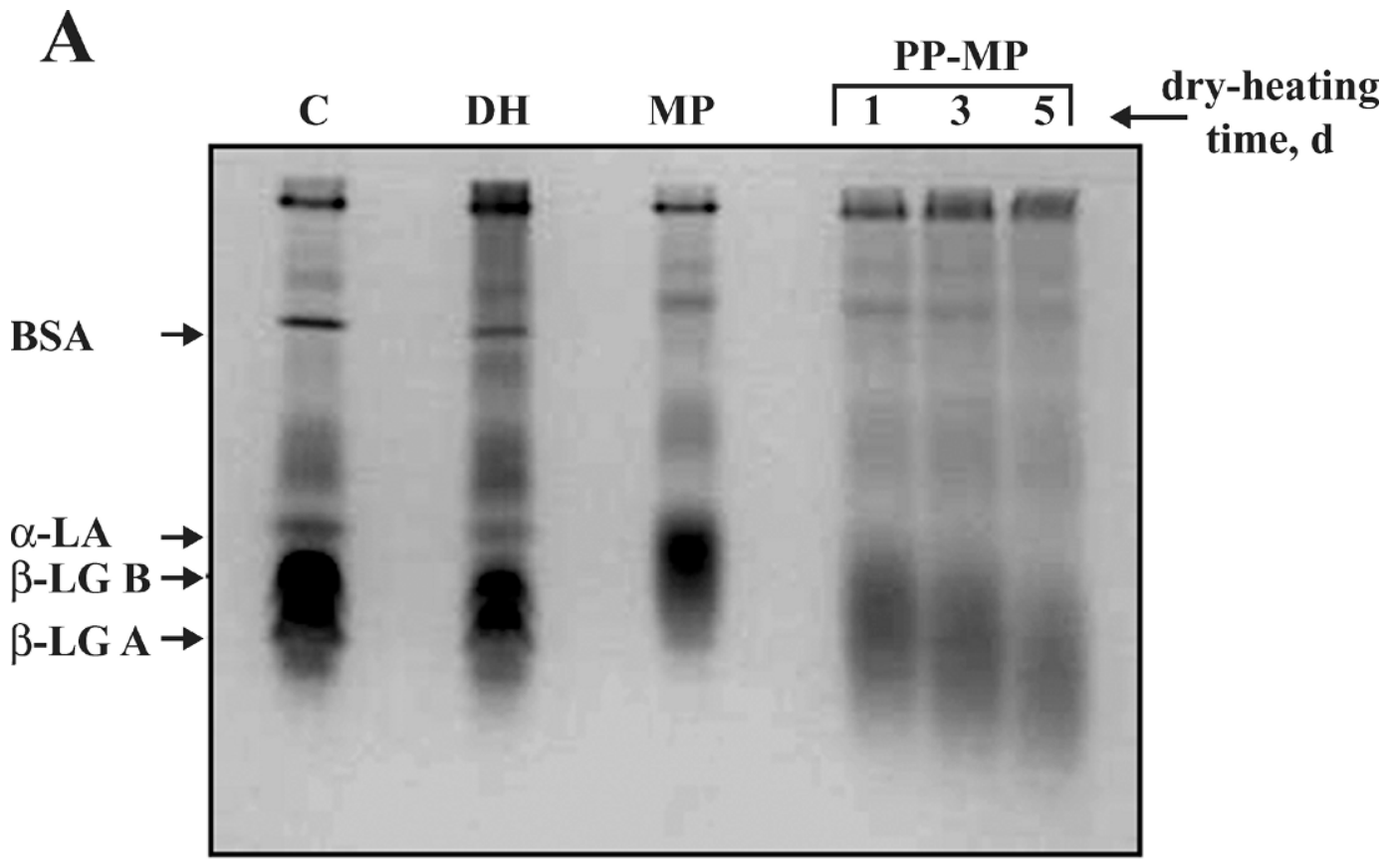

B

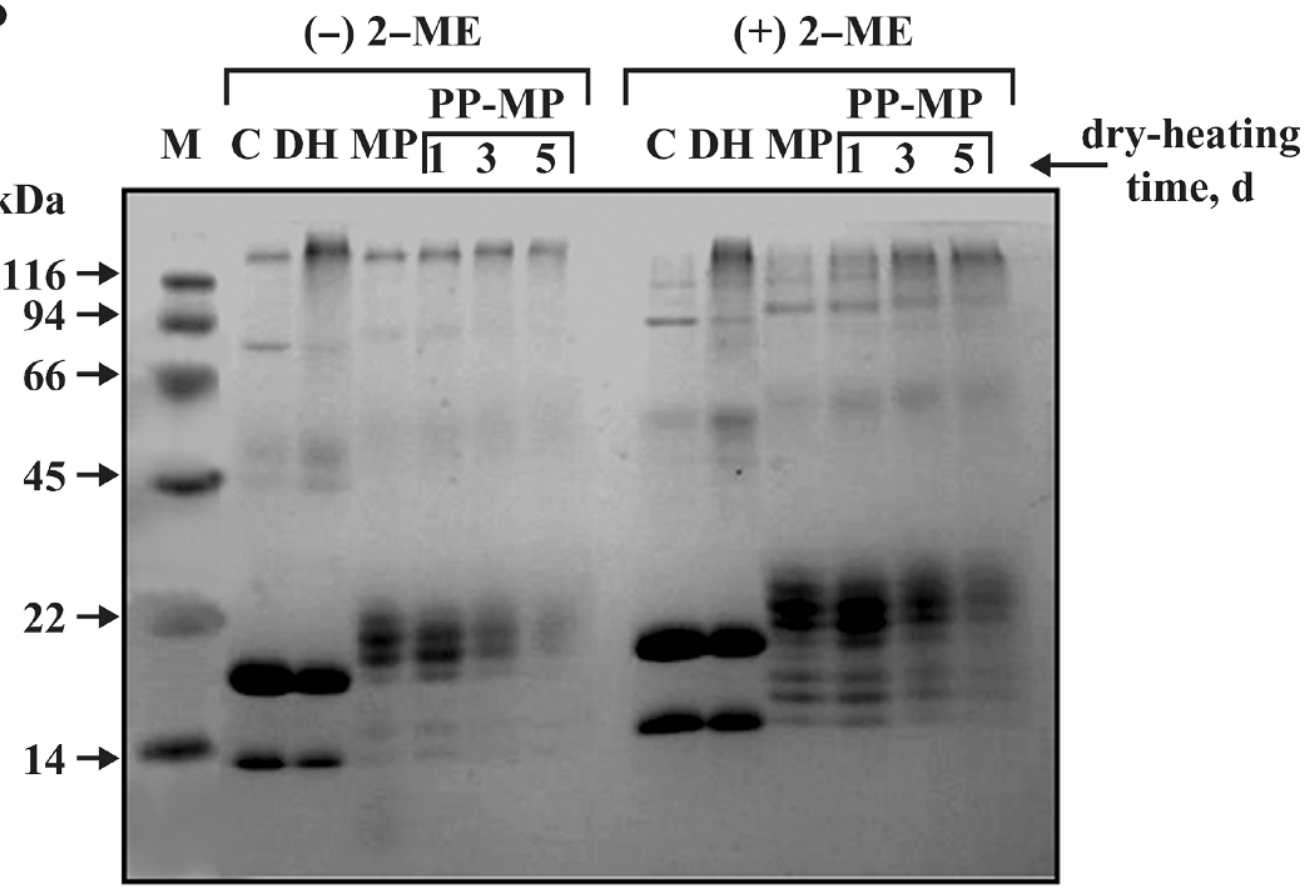

Figure 1. Electrophoretic patterns of control (C), dry heated (DH), maltopentaose-conjugated (MP), and phosphorylated, maltopentaoseconjugated (PP-MP) whey protein isolate (WPI). A) Native PAGE (14\% polyacrylamide gel without SDS); B) SDS-PAGE (14\% polyacrylamide gel with $1.7 \%$ SDS) with (+) and without (-) $5 \%$ 2-mercaptoethanol (2-ME). Lane M = marker protein.

phosphate. Furthermore, the band near $14 \mathrm{kDa}$ also increased in the presence of 2 -mercaptoethanol, indicating that part of $\alpha$-LA was polymerized through disul- fides by dry heating. However, some of the aggregates remained undissociated in the presence of 2-mercaptoethanol. These results indicated that not only disulfide 


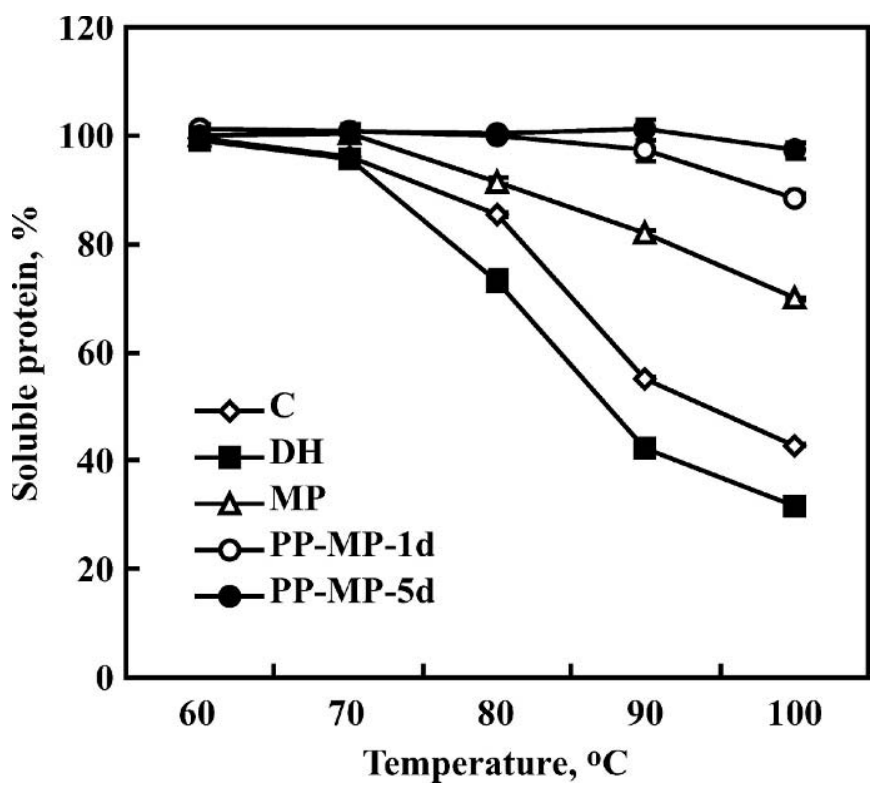

Figure 2. Stability against heat-induced insolubility of control (C), dry heated (DH), maltopentaose-conjugated (MP), and phosphorylated, maltopentaose-conjugated (PP-MP) whey protein isolate (WPI) at various temperatures. Protein sample was $1 \mathrm{~g} / \mathrm{L}$ in $50 \mathrm{mM}$ Tris-HCl buffer ( $\mathrm{pH} 7.0)$ and heated at 60 to $100^{\circ} \mathrm{C}\left(100^{\circ} \mathrm{C}=\right.$ boiling water) for $10 \mathrm{~min}$. All data shown are mean values of 4 determinations, with a deviation of $1 \%$.

bonds but also other types of bonds were formed by dry heating. Covalent bonds other than the disulfide bonds formed in proteins by dry heating have been discussed by some researchers (Kato et al., 1989; Watanabe et al., 1999), but their structures have not yet been elucidated. It has been reported that cross-linking by amidation between carbonyl and $\varepsilon$-amino groups or by transamidation between such groups with the elimination of ammonia occurs upon severe heat treatment in protein molecule(s) (Feeney, 1975). Thus, covalent bonds such as those mentioned above may be formed in WPI on dry heating in the absence and presence of pyrophosphate.

To examine the stability of WPI against heat-induced insolubility at $\mathrm{pH} 7.0,1 \mathrm{~g} / \mathrm{L}$ solutions of C-, DH-, MP-, and PP-MP-WPI dissolved in a $50 \mathrm{~m} M$ Tris-HCl buffer $(\mathrm{pH} 7.0)$ were heated at various temperatures (60 to $100^{\circ} \mathrm{C}$ ), and the soluble proteins were determined. As shown in Figure 2, soluble proteins in the $\mathrm{C}$ - and $\mathrm{DH}$ WPI solutions decreased markedly as heating temperatures increased $>80^{\circ} \mathrm{C}$, but then declined $\sim 31.8 \%$ for DH-WPI and $42.9 \%$ for C-WPI by heating in boiling water for $10 \mathrm{~min}$. In the case of MP-WPI, the decrease of soluble protein heated in boiling water was $69.9 \%$, which was higher than those in C- and DH-WPI, suggesting that the stability of WPI against the heat-induced insolubility at $\mathrm{pH} 7.0$ was somewhat improved by conjugation with MP. However, under the same heat treatment conditions (boiling water/10 min), the soluble protein in PP-MP-WPI-5d solutions was increased even further to $97.2 \%$. These results suggested that although the stability of WPI against heating at $\mathrm{pH} 7.0$ was somewhat improved by glycation, the stability was further improved by phosphorylation. The improved stability of food proteins against heating through the Maillard reaction has been reported by some researchers (Aoki et al., 1999, 2001; Matsudomi et al., 2002). Kato et al. (1995) reported that the heat stability of ovalbumin was improved by conjugation with glucose-6phosphate. Interestingly, in that case, compared with conjugation with glucose, the stability of ovalbumin against heat was much more efficiently improved by conjugation with glucose-6-phosphate, suggesting that phosphate groups played an important role in improving the stability of ovalbumin against heat. In the present study, although phosphate groups were introduced after glycation, they were also essential in retaining the more soluble proteins in solution after heat treatment. It has been reported that the electrostatic-repulsive force is important in helping to prevent the random aggregation of denatured ovalbumin (Kitabatake et al., 1988; Li et al., 2005). The transparent solution obtained in this study is thought to be due to the soluble linear aggregates of PP-MP-WPI resulting from a hydrophobic interaction and the electrostatic-repulsive force between introduced phosphate groups.

\section{Functional Properties of Phosphorylated WPI}

Figure 3 shows the emulsifying activity (A) and stability (B) of C-, DH-, MP-, and PP-MP-WPI. The value of the ordinate at zero time denotes the relative emulsifying activity, and the half-life of initial turbidity reflects the stability of the emulsion. Whey protein is an excellent emulsifier, and in the present study, its emulsifying activity was barely affected by glycation and phosphorylation. The emulsifying stability of WPI decreased slightly by dry heating in the absence of pyrophosphate, which was slightly affected by glycation alone or phosphorylation for $1 \mathrm{~d}$ after glycation. However, the emulsifying stability of PP-MP-WPI-5d was 2.2 times higher than that of MP-WPI. The improved emulsifying stability of PP-MP-WPI-5d may be due to slightly better amphiphilic balance and the prevention of coalescence of oil droplets by electrostatic repulsion force of introduced and negatively charged phosphate groups.

To examine whether the properties of heat-induced WPI gels were improved by phosphorylation, we measured some of those properties. First, we examined the effect of $\mathrm{NaCl}$ concentration on the appearance of WPI gels at $595 \mathrm{~nm}$. As shown in Figure 4, the turbidity of C- 

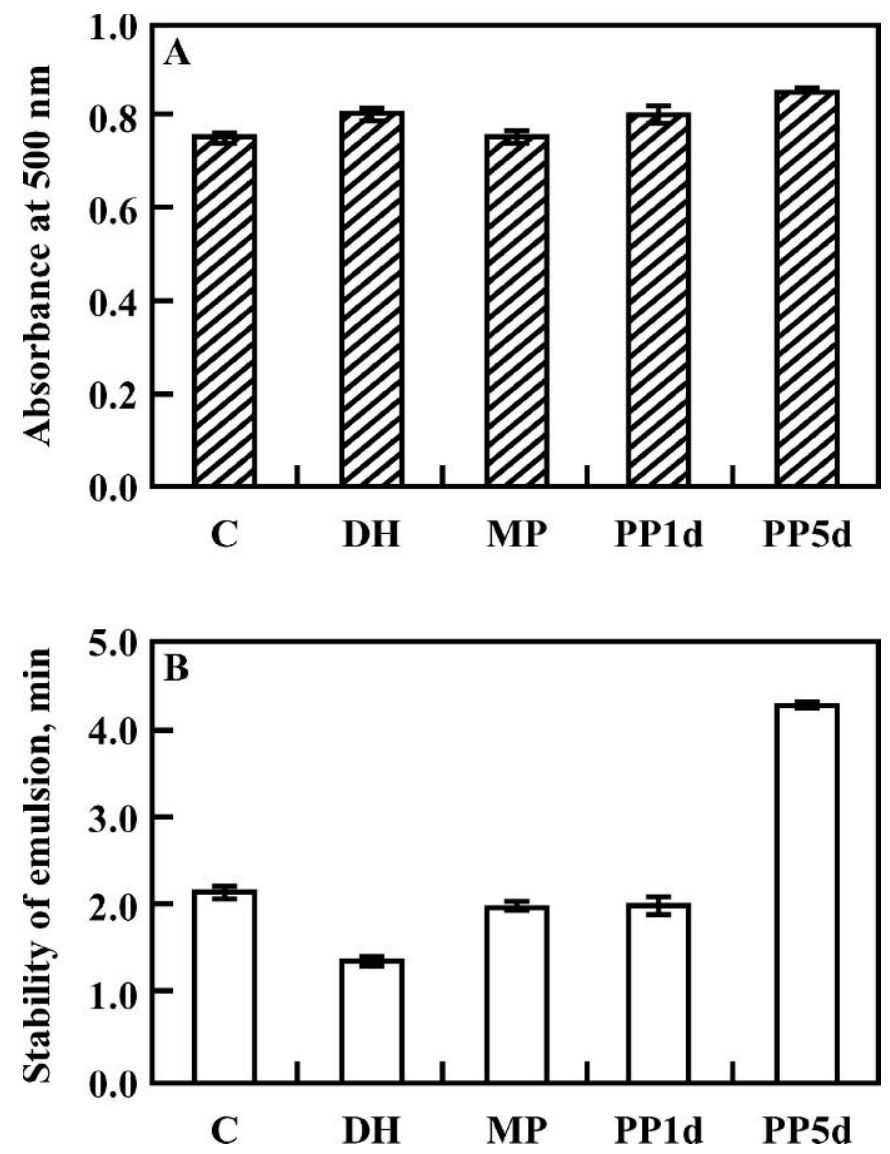

Figure 3. Emulsifying activity given as A) turbidity (absorbance at $500 \mathrm{~nm}$ ) and B) stability as half time of emulsions, respectively of control (C), dry heated (DH), maltopentaose-conjugated (MP), and phosphorylated, maltopentaose-conjugated $(\mathrm{PP})$ whey protein isolate (WPI). Each value represents the mean \pm SD $(n=4)$.

WPI increased with an increase in $\mathrm{NaCl}$ concentration. Although the gel turbidity was slightly reduced by glycation, the gels remained opaque at a $\mathrm{NaCl}$ concentration of $>25 \mathrm{~m} M$. On the other hand, the turbidity of PPMP-WPI gels was much lower than that of C- and MPWPI, becoming very transparent under visual inspection at a $\mathrm{NaCl}$ concentration of $<100 \mathrm{mM}$ (data not shown). Thus, a $\mathrm{NaCl}$ concentration of $75 \mathrm{~m} M$ was used in subsequent experiments for the measurement of gel properties. Next, we examined the hardness, resiliency, and WHC of C-, MP-, and PP-MP-WPI gels, although the properties of PP-MP-WPI-5d were not measured because of its overly soft texture. As shown in Table 2, the hardness of MP-WPI and PP-MP-WPI gels was higher than that of C-WPI, whereas there was no significant difference between those of MP- and PP-MPWPI. Compared with C-WPI, the resiliency and WHC of WPI increased by conjugation with MP, and increased even further by phosphorylation. The turbidities of WPI solution (before heating, $75 \mathrm{mM} \mathrm{NaCl}$ ) and gels (after

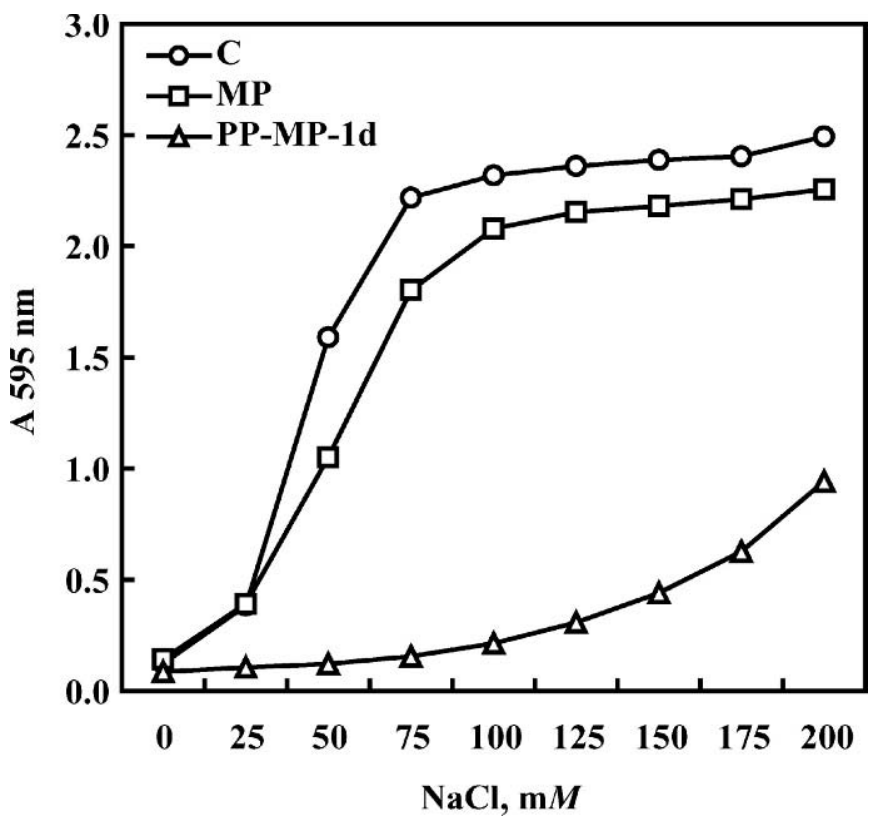

Figure 4. Effect of $\mathrm{NaCl}$ concentrations ( 0 to $200 \mathrm{mM}$ ) on the turbidity of heat-induced whey protein isolate (WPI) gels $(\mathrm{C}=$ control WPI; MP = maltopentaose-conjugated WPI; and PP-MP-1d = phosphorylated, maltopentaose-conjugated WPI after $1 \mathrm{~d}$ of dry heating). Absorbance at $595 \mathrm{~nm}$ was used as an indicator of turbidity. All data shown are the mean value of the 2 determinations, with a deviation of $1 \%$.

heating) are shown in Table 2. Before heating, although the turbidity of all samples was low (as expected), that of C- and MP-WPI gels increased after heating at $90^{\circ} \mathrm{C}$ for $1 \mathrm{~h}$. However, the turbidity of PP-MP-WPI was much lower than that of C- and MP-WPI. Furthermore, it seems that a transparent heat-induced PP-MP-WPI gel could be produced at a relatively higher $\mathrm{NaCl}$ concentration, suggesting that a transparent heat-induced WPI gel with better texture was obtained by phosphorylation after glycation. In a previous paper (Li et al., 2004), we reported that the properties of EWP gels were improved by phosphorylation. The improved WHC and increased transparency of PP-MP-WPI (1 d) gel in the present study is considered to be due to the construction of a uniform network (Woodward and Cotterill, 1986; Yasuda et al., 1986). Interestingly, in the present study, although PP-MP-WPI-5d contained more phosphorus than did PP-MP-WPI-1d, its heat-induced gel was much softer than that of PP-MP-WPI-1d at $75 \mathrm{mM} \mathrm{NaCl}$, most likely due to too strong electrostatic repulsive force of phosphate groups (Hatta et al., 1986). Thus, the use of $1 \mathrm{~d}$ of dry heating time after glycation is recommended when a heat-induced PP-MP-WPI gel is prepared.

The solubilization of the calcium phosphate of WPI was examined using the method of artificial casein micelles, where the final concentrations of calcium, $\mathrm{Pi}$, 
Table 2. Gelling properties of heat-induced gels from different whey protein isolates (WPI). ${ }^{1}$

\begin{tabular}{|c|c|c|c|c|}
\hline Sample $^{3}$ & $\begin{array}{c}\text { Hardness } \\
(\text { gram-force/cm²) }\end{array}$ & $\begin{array}{l}\text { Resiliency } \\
(\%)\end{array}$ & $\begin{array}{l}\text { Turbidity }^{2} \\
\text { of solution } \\
\text { before/gel } \\
\text { after heating }\end{array}$ & $\begin{array}{l}\text { Water-holding } \\
\text { capacity }(\%)\end{array}$ \\
\hline C-WPI & $516 \pm 34^{\mathrm{a}}$ & $59.0 \pm 1.3^{\mathrm{a}}$ & $0.11 / 2.22$ & $75.1 \pm 1.3^{\mathrm{a}}$ \\
\hline MP-WPI & $684 \pm 16^{\mathrm{b}}$ & $60.9 \pm 1.0^{b}$ & $0.10 / 1.80$ & $88.8 \pm 1.1^{\mathrm{b}}$ \\
\hline PP-MP-WPI-1d & $708 \pm 114^{b}$ & $76.4 \pm 2.7^{\mathrm{c}}$ & $0.10 / 0.16$ & $92.1 \pm 0.5^{\mathrm{c}}$ \\
\hline
\end{tabular}

and citrate were 30,22 , and $10 \mathrm{~m} M$, respectively. The solubilized calcium and $\mathrm{Pi}$ were estimated from the difference between their soluble concentrations in the solutions with and without protein. As shown in Figure 5, although C- or MP-WPI had only a slight calcium phosphate-solubilizing ability, it was enhanced by phosphorylation after glycation. In the presence of $2 \%$ protein, PP-MP-WPI-5d solubilized $12.9 \mathrm{mM} \mathrm{Pi}$ and 20.0 $\mathrm{m} M$ calcium, showing that the calcium phosphate-solubilizing ability of WPI was efficiently enhanced by phosphorylation after glycation with MP. Thus, PP-MP-WPI may be expected to enhance the absorption of calcium.

The roles of phosphate groups such as their physiological (Kitazawa et al., 1996, 1998, 2000) and immune functions (Hata et al., 1998, 1999; Otani et al., 2000)

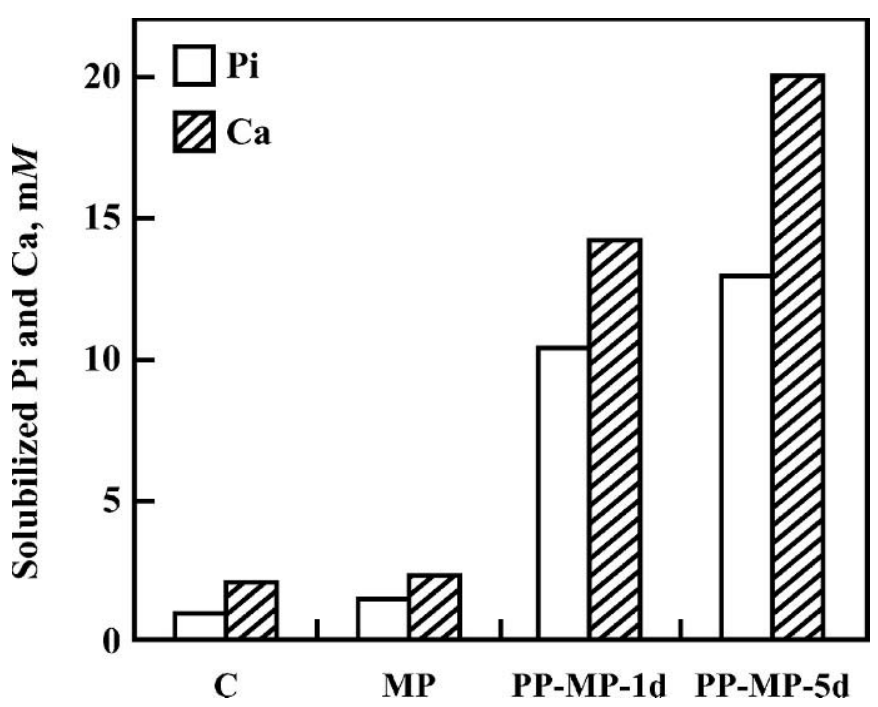

Figure 5. Calcium phosphate-solubilizing ability of control (C), dry heated (DH), maltopentaose-conjugated (MP), and phosphorylated, maltopentaose-conjugated (PP-MP) whey protein isolate (WPI). Test solution contained $20 \mathrm{~g} / \mathrm{L}$ protein, $30 \mathrm{~m} M$ calcium, $22 \mathrm{mM} \mathrm{Pi}$, and $10 \mathrm{~m} M$ citrate, with $\mathrm{pH}$ adjusted to 6.7 with $1 M \mathrm{KOH}$. Each column shows mean values of 2 determinations, with a deviation of less than $1 \%$. have been reported. Thus, physiological and immune functions of PP-MP-WPI also can be expected.

\section{CONCLUSIONS}

The present study demonstrated that WPI could be efficiently phosphorylated by dry heating in the presence of pyrophosphate after conjugation with MP, and that its functional properties such as stability against heat-induced insolubility and calcium phosphate-solubilizing ability were improved by phosphorylation. In addition, the gelling properties, such as the hardness, resiliency, and WHC of heat-induced gels of WPI were markedly improved, and the gel was rendered transparent by phosphorylation. Thus, phosphorylation by dry heating in the presence of pyrophosphate after glycation with MP seems to be a useful method for improving the functional properties of WPI. Further studies are underway in our laboratory to determine the possible causative factors responsible for the improved functional properties of PP-MP-WPI.

\section{ACKNOWLEDGMENT}

This work was supported by a Grant-in-Aid (17580238) from the Ministry of Education, Culture, Sports, Science, and Technology of Japan.

\section{REFERENCES}

Aoki, T. 1989. Incorporation of individual casein constituents into casein aggregates cross-linked by colloidal calcium phosphate in artificial casein micelles. J. Dairy Res. 56:613-618.

Aoki, T., T. Fukumoto, T. Kimura, Y. Kato, and T. Matsuda. 1994 Whey protein- and egg white protein-glucose 6-phosphate conjugates with calcium phosphate-solubilizing properties. Biosci. Biotechnol. Biochem. 58:1727-1728.

Aoki, T., Y. Hiidome, K. Kitahata, Y. Sugimoto, H. R. Ibrahim, T. Kimura, and Y. Kato. 1999. Improvement of functional properties of ovalbumin by conjugation with glucuronic acid through the Maillard reaction. Food Res. Int. 32:129-133.

Aoki, T., Y. Hiidome, Y. Sugimoto, H. R. Ibrahim, and Y. Kato. 2001. Modification of ovalbumin with oligogalacturonic acid through the Maillard reaction. Food Res. Int. 34:127-132. 
Aoki, T., K. Kitahata, T. Fukumoto, Y. Sugimoto, H. R. Ibrahim, T. Kimura, Y. Kato, and T. Matsuda. 1997. Improvement of functional properties of $\beta$-lactoglobulin by conjugation with glucose6-phosphate through the Maillard reaction. Food Res. Int. 30:401-406

Chen, P. S., T. Y. Toribara, and H. Warner. 1956. Microdetermination of phosphorus. Anal. Chem. 28:1756-1758.

Chobert, J. M. 2003. Milk protein modification to improve functional and biological properties. Page 1-60 in Advances in Food and Nutrition Research. Vol. 47. S. L. Taylor, ed. Academic Press, New York, NY.

Dubois, M., K. A. Gilles, J. K. Hamilton, P. A. Rebers, and F. Smith. 1956. Colorimetric method for determination of sugars and related substances. Anal. Chem. 28:350-356.

Feeney, R. E. 1975. Chemical changes in food proteins. Page 233254 in Evaluation of Proteins for Humans. C. E. Bodwell, ed. AVI Publishers, Westport, CT.

Fox, P. F. 2003. Milk proteins: General and historical aspects. Page 1-41 in Advanced Dairy Chemistry. Vol. 1. P. F. Fox and P. L. H. McSweeney, ed. Plenum Publishers, New York, NY.

Hata, I., S. Higashiyama, and H. Otani. 1998. Identification of a phosphopeptide in bovine $\alpha_{\mathrm{s} 1}$-casein digest as a factor influencing proliferation and immunoglobulin production in lymphocyte cultures. J. Dairy Res. 65:569-578.

Hata, I., J. Ueda, and H. Otani. 1999. Immunostimulatory action of a commercially available casein phosphopeptide preparation, CPP-III, in cell cultures. Milchwissenschaft 54:3-7.

Hatta, H., N. Kitabatake, and E. Doi. 1986. Turbidity and hardness of a heat-induced gel of hen egg ovalbumin. Agric. Biol. Chem. 50:2083-2089.

Kang, J. I., Y. Matsumura, and T. Mori. 1991. Characterization of texture and mechanical properties of heat-induced soy protein gels. J. Am. Oil Chem. Soc. 68:339-345.

Kato, A., H. R. Ibrahim, H. Watanabe, K. Honma, and K. Kobayashi. 1989. New approach to improve the gelling and surface functional properties of dried egg white by heating in dry state. J. Agric. Food Chem. 38:32-37.

Kato, Y., T. Aoki, N. Kato, R. Nakamura, and T. Matsuda. 1995. Modification of ovalbumin with glucose 6-phosphate by aminocarbonyl reaction. Improvement of protein heat stability and emulsifying activity. J. Agric. Food Chem. 43:301-305.

Kim, M., M. Saltmarch, and T. P. Labuzu. 1981. Non-enzymatic browning of hygroscopic whey powders in open versus sealed pouches. J. Food Process. Preserv. 5:49-57.

Kinsella, J. E., and D. M. Whitehead. 1989. Proteins in whey: Chemical, physical, and functional properties. Adv. Food Nutr. Res. 33:343-438.

Kitabatake, N., A. Ishida, and E. Doi. 1988. Physicochemical and functional properties of hen ovalbumin dephosphorylated by acid phosphatase. Agric. Biol. Chem. 52:967-973.

Kitabatake, N., and N. Kinekawa. 1995. Turbidity measurement of heated egg proteins using a microplate system. Food Chem. 54:201-203.

Kitazawa, H., T. Harata, J. Uemura, T. Saito, T. Kaneko, and T. Itoh. 1998. Phosphate group requirement for mitogenic activation of lymphocytes by an extracellular phosphopolysaccharide from Lactobacillus delbrueckii ssp. bulgaricus. Int. J. Food Microbiol. 40:169-175.

Kitazawa, H., Y. Ishii, J. Uemura, T. Saito, T. Kaneko, K. Noda, and T. Itoh. 2000. Augmentation of macrophage functions by an extracellular phosphopolysaccharide from Lactobacillus delbrueckii ssp. bulgaricus. Food Microbiol. 17:109-118.
Kitazawa, H., T. Itoh, Y. Tomioka, M. Mizugaki, and T. Yamaguchi. 1996. Induction of IFN- $\gamma$ and IL-l $\alpha$ production in macrophages stimulated with phosphopolysaccharide produced by Lactococcus lactis ssp. cremoris. Int. J. Food Microbiol. 31:99-106.

Laemmli, U. K. 1970. Cleavage of structural proteins during the assembly of the head of bacteriophage T4. Nature 227:680-685.

Li, C. P., Y. Hayashi, H. Shinohara, H. R. Ibrahim, Y. Sugimoto, J. Kurawaki, N. Matsudomi, and T. Aoki. 2005. Phosphorylation of ovalbumin by dry-heating in the presence of pyrophosphate: Effect on protein structure and some properties. J. Agric. Food Chem. 53:4962-4967.

Li, C. P., H. R. Ibrahim, Y. Sugimoto, H. Hatta, and T. Aoki. 2004. Improvement of functional properties of egg white protein through phosphorylation by dry-heating in the presence of pyrophosphate. J. Agric. Food Chem. 52:5752-5758.

Li, C. P., A. S. Salvador, H. R. Ibrahim, Y. Sugimoto, and T. Aoki. 2003. Phosphorylation of egg white proteins by dry-heating in the presence of phosphate. J. Agric. Food Chem. 51:6808-6815.

Matheis, G., and J. R. Whitaker. 1984. Chemical phosphorylation of food proteins: An overview and a prospectus. J. Agric. Food Chem. 32:699-705.

Matsudomi, N., K. Nakano, A. Soma, and A. Ochi. 2002. Improvement of gel properties of dried egg white by modification with galactomannan through the Maillard reaction. J. Agric. Food Chem. 50:4113-4118.

Nakano, T., A. S. Salvador, J. Tamochi, Y. Sugimoto, H. R. Ibrahim, Y. Toba, S. Aoe, H. Kawakami, and T. Aoki. 2003. Phosphorylation of starch and dextrin by dry-heating in the presence of phosphate, and their calcium phosphate-solubilizing ability. Nahrung Food 47:274-278.

Otani, H., H. Kitamura, M. Park, Y. Kihara, T. Oshida, S. Kusuhara, and K. Sawada. 2000. Enhancement of intestinal IgA levels in piglets by oral administration of a commercially available casein phosphopeptide preparation. Milchwissenschaft 55:429-432.

Pearce, K. N., and J. E. Kinsella. 1978. Emulsifying properties of proteins: Evaluation of a turbidimetric technique. J. Agric. Food Chem. 26:716-723.

Seguro, K., and M. Motoki. 1989. Enzymatic phosphorylation of soybean proteins by protein kinase. Agric. Biol. Chem. 53:3263-3268.

Sitohy, M., J.-M. Chobert, and T. Haertlé. 1995. Phosphorylation of $\beta$-lactoglobulin under mild conditions. J. Agric. Food Chem. 43:59-62.

Sitohy, M. Z., S. M. Labib, S. S. EI-Saadany, and M. F. Ramadan. 2000. Optimizing the conditions for starch dry phosphorylation with sodium mono- and dihydrogen orthophosphate under heat and vacuum. Starch/Die Stärke 52:95-100.

Tarelli, E., and S. F. Wheeler. 1994. Drying from phosphate-buffered solutions can result in the phosphorylation of primary and secondary alcohol groups of saccharides, hydroxlyated amino acids, proteins, and glycoproteins. Anal. Biochem. 222:196-201.

Watanabe, K., J. Q. Xu, and M. Shimoyamada. 1999. Inhibiting effects of egg white dry-heated at $120^{\circ} \mathrm{C}$ on heat aggregation and coagulation of egg white and characteristics of dry-heated egg white. J. Agric. Food Chem. 47:4083-4088.

Woo, S. L., and T. Richardson. 1983. Functional properties of phosphorylated $\beta$-lactoglobulin. J. Dairy Sci. 66:984-987.

Woodward, S. A., and O. J. Cotterill. 1986. Texture and microstructure of heat-formed egg white gels. J. Food Sci. 51:333-339.

Yasuda, K., R. Nakamura, and S. Hayakawa. 1986. Factors affecting heat-induced gel formation of bovine serum albumin. J. Food Sci. 51:1289-1292. 